\title{
Management of the moribund carbon monoxide victim
}

\author{
L. F. THOMSON*, S. N. MARDEL ${ }^{+}, A \cdot \mathrm{JACK}^{*} \&$ \\ T. G. SHIELDS* \\ ${ }^{*}$ Hyperbaric Medicine Unit, Aberdeen Royal Infirmary, and ${ }^{\dagger}$ Accident $\mathcal{E}$ Emergency \\ Department, Aberdeen Royal Infirmary, Aberdeen.
}

\section{SUMMARY}

Carbon monoxide (CO) poisoning is the commonest single cause of fatal poisoning in the U.K. (Broome \& Pearson, 1988). The clinical features are numerous and include headache, fatigue, dizziness, confusion, memory loss, paraesthesia, chest pain, abdominal pain, nausea, and diarrhoea as well as coma, convulsions and death. Without adequate treatment many patients develop neuropsychiatric sequelae including headaches, irritability, memory loss, confusion and personality changes. The diagnosis of $\mathrm{CO}$ poisoning is often suggested only by circumstances surrounding the victim, and remains a challenge to the A\&E department. Hyperbaric oxygen therapy $(\mathrm{HBO})$ is internationally accepted as the most powerful form of treatment in severe cases (Drug \& Therapeutics Bulletin, 1988; Lowe-Ponsford \& Henry, 1989). However, in the U.K. treatment with HBO is often not considered due to lack of hyperbaric facilities (Meredith \& Vale, 1988; Anand et al., 1988), and due to inadequate awareness on the part of hospital staff. We report a case of a patient deeply unconscious as a result of $\mathrm{CO}$ poisoning, in which serial treatments with $\mathrm{HBO}$ over a period of 14 days, produced dramatic results.

\section{CASE REPORT}

A 41-year-old man was found unconscious in his car with the exhaust pipe connected by a hose to the interior. He was taken by ambulance to the nearest hospital, where on arrival $1 \mathrm{~h}$ after removal from the car, he was found to be

Correspondence: $\operatorname{Dr}$ L. F. Thomson, Department of Anaesthetics, Aberdeen Royal Infirmary, Foresterhill, AB9 $2 Z B$ or Dr T. G. Shields, RGIT Hyperbaric Research Unit, Robert Gordon Institute of Technology, School Hill, Aberdeen $A B 1$ 1FR. 
unconscious, responding to painful stimuli with extensor posturing (Glasgow Coma Scale [G.C.S.] of 4), but breathing spontaneously. Generalized convulsions occurred, and diazepam ( $15 \mathrm{mg}$ i.v.) was given. He was unable to tolerate intubation and was transferred by ambulance with oxygen administered by mask at $151 \mathrm{~min}^{-1}$ to the major area hospital, unfortunately 50 miles in the opposite direction to the nearest Hyperbaric Unit. His clinical condition remained unchanged. Blood samples taken $3 \mathrm{~h}$ after removal from the car showed a carboxyhaemoglobin level $(\mathrm{COHb})$ of $17.5 \%$, and mild metabolic acidosis. A drug screen was negative. The calculated $\mathrm{COHb}$ at the time of removal from the car was $35 \%$ (Clark et al., 1981). The patient continued to show signs of cerebral irritation, with decerebrate extensor rigidity, and was given $200 \mathrm{ml} 20 \%$ mannitol i.v. over $20 \mathrm{~min}$. He still could not tolerate intubation and was transferred on oxygen by mask to the Hyperbaric Medicine Unit at Aberdeen Royal Infirmary, arriving $5 \mathrm{~h} 35 \mathrm{~min}$ after removal from the car. He remained unconscious, with extensor posturing to painful stimuli (G.C.S. 4), and dilated pupils reacting sluggishly to light. Immediate compression was carried out to 3.0 ATA with $100 \%$ oxygen supplied on a demand breathing system. There was a rapid response with a lightening of conscious level, flexor response to pain (G.C.S. 7), and pupils reacting briskly to light. A blood sample taken $2 \mathrm{~h}$ after admission showed $\mathrm{COHb}$ of $2 \%$. During the return to atmospheric pressure (with a consequent fall in oxygen partial pressure), however, there was a progressive relapse with deterioration of conscious level, re-appearance of rigidity, extensor in the right arm and flexor in the left (G.C.S. 5), and loss of pupil responsiveness to light. Plantar responses were briskly extensor throughout this time. Condition on exit from the pressure chamber was generally improved from admission.

Following $6 \mathrm{~h}$ on the ward the patient showed some improvement, with a lightening of conscious level and pupils now reactive to light. A further session of $90 \mathrm{~min}$ at 2 ATA on $100 \%$ oxygen produced a marked improvement during treatment, with a lessening of rigidity, and increased responsiveness to pain with purposeful arm movements (G.C.S. 8). During a third session $6 \mathrm{~h}$ later his conscious level became considerably lighter (G.C.S. 10), but showed gradual deterioration following return to the ward. A fourth session on day 2, 36h after admission produced a dramatic response, with the patient regaining consciousness whilst breathing oxygen inside the chamber and attempting conversation, although disorientated. That afternoon, a fifth session again produced an improvement, with the patient now well orientated and with insight into the background of his condition, and also able to stand unaided.

Overnight on the ward he became confused and disorientated, but during treatment the following morning he became noticeably more alert and able to converse sensibly. On the ward the improvement was maintained for only a few hours and he then became more flattened in affect, tired and staggering towards the left. In the afternoon he was treated again, with a marked improvement in mood and co-ordination occurring almost immediately on exposure to $100 \%$ oxygen at 2 ATA.

The pattern continued, with maximal improvement during and immediately after each exposure to $\mathrm{HBO}$, but noticeable deterioration between each session. The overall picture was of immense improvement. 
By day 4, the patient was capable of undertaking formal neuropsychometric assessment by a psychologist. This showed him to be disorientated, with severe deficits of short-term memory, learning, fine motor control and conceptual tracking. Daily $\mathrm{HBO}$ exposures were carried out, and on day 7 neuropsychometric testing showed him to be fully orientated and able to exhibit fine motor skills, with marked improvement in short-term memory, and a short learning curve. Further testing on day 9 showed no improvement and his performance appeared to have reached a plateau. On day 11 however, following a day without treatment, neuropsychometric testing revealed a deterioration in short-term verbal memory, with loss of the learning curve, and poorer scores on conceptual tracking and fine motor control. HBO sessions were recommenced and continued daily until day 14 when short-term memory tests, conceptual tracking and fine motor skills had greatly improved and a near normal learning curve was obtained. The patient himself noted an increase in clarity of thought and general well-being over the previous 4 days.

Magnetic resonance imaging of the brain, and radioisotope imaging (HMPAO) of the regional cerebral blood flow performed on day 9 were normal.

On review at 5 weeks the patient described himself as completely back to normal, and neuropsychometric testing showed that his recovery had been maintained.

\section{DISCUSSION}

The presentation of this case and his initial management is not unusual, and his treatment in the early stages could have been improved by the early administration of $100 \%$ oxygen. To achieve this paralysis and endotracheal intubation may have been indicated, particularly in view of the sedation the patient had already received. There was a significant delay in this patient receiving HBO therapy, and this is not uncommon as HBO therapy is often not considered, or the location of the nearest $\mathrm{HBO}$ facility is unknown.

There are numerous reports where treatment with $\mathrm{HBO}$ has produced similar dramatic results of complete recovery in previously deeply unconscious patients, often despite considerable delay prior to treatment (Myers et al., 1981). However this patient demonstrated a stepwise improvement with each successive HBO treatment over a period of 14 days, long after $\mathrm{COHb}$ levels have returned to normal and this is only explained by current views on the mechanism of $\mathrm{CO}$ toxicity.

These mechanisms have been well described. $\mathrm{CO}$ has a high affinity for haemoglobin and causes a shift of the oxyhaemoglobin dissociation curve towards the left, so that less oxygen is available for release to tissues with consequent tissue anoxia. Of even more importance in $\mathrm{CO}$ poisoning is tissue toxicity due to binding of $\mathrm{CO}$ to other haem-containing proteins particularly myoglobin, cytochrome oxidase and P450, leading to disruption of intracellular respiration (Kindwall, 1977; Piantadosi, 1987). The rate of intracellular washout is not known, but is believed to be much longer than that for haemoglobin (Piantadosi, 1987). This could explain the frequent discrepancy between $\mathrm{COHb}$ levels and the clinical state of the patient (Myers et al., 1979; Noorkool \& Kirkpatrick, 1985). 
Cerebral oedema is a frequent sequel to severe $\mathrm{CO}$ poisoning. $\mathrm{HBO}$ is well recognized as a powerful cerebral vasoconstrictor, whilst still providing sufficient oxygen for normal metabolism, and has been shown to reduce intracranial pressure due to cerebral oedema by $30 \%$ within $3 \mathrm{~min}$ at 2 ATA (Sukoff \& Ragatz, 1982).

Many authorities, including the National Poisons Information Service recommend $\mathrm{HBO}$ for any patient suffering from other than mild exposure and note its benefits in reversing or reducing the duration of coma (Drug \& Therapeutics Bulletin, 1988; Lowe-Ponsford \& Henry, 1989). Studies show a varying incidence of delayed neuropsychiatric sequelae of between $10 \%$ and $43 \%$ in victims of moderate to severe $\mathrm{CO}$ poisoning, which is greatly reduced in those treated with $\mathrm{HBO}$ (Garland \& Pearce, 1967; Smith \& Brandon, 1973; Myers et al., 1985; Min, 1986). HBO has also proved effective in the treatment of neuropsychiatric symptoms developing several days after conventional treatment with $100 \%$ oxygen (Myers et al., 1985). Several authors have described the need for repeated sessions of $\mathrm{HBO}$ due to incomplete resolution or recurrence of symptoms between treatments (James, 1988; Lowe-Ponsford \& Henry, 1989).

The following recommendations for the use of $\mathrm{HBO}$ following $\mathrm{CO}$ poisoning are taken from the Drug \& Therapeutics Bulletin, October 1988:-

(1) patients who are or have been unconscious

(2) patients who on thorough testing show neurological or psychiatric symptoms or signs other than a mild headache

(3) patients with cardiac complications

(4) patients with $\mathrm{COHb}$ levels above $40 \%$, regardless of symptoms (Meredith \& Vale, 1988).

(5) pregnant women, who may be at special risk after exposure to CO.

Ideally the initial management should include the administration of $100 \%$ oxygen. This is difficult to achieve with conventional mask delivery systems and even with maximal flow rates most masks will only achieve $60 \%$ unless a reservoir system is used. Where the safety of the airway or adequacy of ventilation is in doubt then the patient should be intubated and ventilated. The management of this patient could have been improved if at the stage of sedating him for his convulsions, he was paralysed to allow intubation and ventilation. An anaesthetist should therefore have been closely involved in the initial management and subsequent transfer of this patient to a chamber with suitable facilities. However, it is unfortunate that many of the hyperbaric facilities available in the U.K. are monoplace (one-man) chambers and are therefore unsuitable for patients with potential airway or ventilatory problems requiring a medical attendant. Furthermore any resuscitation measures such as intubation or ventilation must be instituted regardless of the subsequent need for $\mathrm{HBO}$ therapy.

\section{CONCLUSION}

The efficacy of HBO therapy is widely accepted internationally. Outside the U.K. emergency personnel will transport $\mathrm{CO}$ poisoned patients directly to the nearest available hyperbaric unit (Kindwall, 1977). Psychometric screening tests are 
routinely used to detect cerebral impairment, and patients are treated on clinical condition rather than carboxyhaemoglobin level. Unfortunately this policy is rarely carried out in the U.K., and HBO is seldom considered. Distance from a hyperbaric chamber should not necessarily prevent access to $\mathrm{HBO}$, since stable comatose patients can be transferred great distance and may make an excellent recovery (Noorkool \& Kirkpatrick, 1985). The A\&E department is usually first to receive victims of $\mathrm{CO}$ poisoning; all A\&E and medical staff should know the location of the nearest available recompression chamber (Table 1), so that patients are not denied access to such an effective therapy.

Table 1. NHS associated chambers.

\begin{tabular}{|c|c|c|c|}
\hline Location & Description & $\begin{array}{l}\text { Consultant } \\
\text { in charge }\end{array}$ & $\begin{array}{l}\text { Contact } \\
\text { number }\end{array}$ \\
\hline $\begin{array}{l}\text { Diving Diseases } \\
\text { Research Centre, } \\
\text { Plymouth }\end{array}$ & $\begin{array}{l}\text { Multiplace } \\
6 \text { persons } \\
31 \text { bar }\end{array}$ & Dr M. Cross & $\begin{array}{l}0752408093 \\
\text { Out of hours aircall via } \\
0752261910\end{array}$ \\
\hline $\begin{array}{l}\text { Peterborough District } \\
\text { Hospital-Intensive } \\
\text { Care Unit }\end{array}$ & $\begin{array}{l}\text { Monoplace } \\
3 \text { bar }\end{array}$ & Dr P. Reed & $\begin{array}{l}073367451 \\
\text { or via on call anaesthetic } \\
\text { registrar. }\end{array}$ \\
\hline $\begin{array}{l}\text { Whipps Cross Hospital } \\
\text { London, Intensive Care } \\
\text { Unit }\end{array}$ & $\begin{array}{l}\text { Monoplace }(\times 2) \\
3 \text { bar }\end{array}$ & $\begin{array}{l}\text { Dr M. Hamilton- } \\
\text { Farrell }\end{array}$ & $\begin{array}{l}0815395522 \\
\text { or via on call consultant } \\
\text { in I.T.U. }\end{array}$ \\
\hline $\begin{array}{l}\text { Monsall Hospital, } \\
\text { Manchester }\end{array}$ & $\begin{array}{l}\text { Monoplace } \\
3 \text { bar }\end{array}$ & Dr E. Dunbar & $\begin{array}{l}0612052393 \\
\text { or via on call consultant } \\
\text { for infectious diseases }\end{array}$ \\
\hline $\begin{array}{l}\text { Glan Clwyd Hospital, } \\
\text { North Wales }\end{array}$ & $\begin{array}{l}\text { Monoplace } \\
2 \text { bar }\end{array}$ & Dr J. Clark & $\begin{array}{l}0745583910 \\
\text { via on-call ODA or ITU staff }\end{array}$ \\
\hline $\begin{array}{l}\text { Craigavan Hospital, } \\
\text { Northern Ireland }\end{array}$ & $\begin{array}{l}\text { Multiplace } \\
8 \text { bar }\end{array}$ & Dr J. Galway & $\begin{array}{l}0762334444 \\
\text { or contact via } A \& E \text {. }\end{array}$ \\
\hline $\begin{array}{l}\text { Royal Victoria Hospital, } \\
\text { Newcastle }\end{array}$ & $\begin{array}{l}\text { Multiplace } \\
5 \text { bar }\end{array}$ & Mr. J. Pooley & $\begin{array}{l}0912226000 \\
\text { Available during working } \\
\text { hours only. }\end{array}$ \\
\hline $\begin{array}{l}\text { Aberdeen Royal } \\
\text { Infirmary }\end{array}$ & $\begin{array}{l}\text { Multiplace } \\
31 \text { bar }\end{array}$ & Dr T. Shields & $\begin{array}{l}0224681818 \text { ext } 53263 \\
\text { Call-out via Hospital Switchboard }\end{array}$ \\
\hline $\begin{array}{l}\text { Ministry of Defence } \\
\text { Chambers (various } \\
\text { U.K. sites) }\end{array}$ & & & $\begin{array}{l}\text { Contact via Diving } \\
\text { Emergency Doctor, } \\
\text { HMS Vernon, Portsmouth } \\
0705818888\end{array}$ \\
\hline
\end{tabular}

Notes (1) This is not an exhaustive list there are other chambers around the country; primarily for diving emergencies. These are listed together with clinical usage in Survey of Clinical Hyperbaric Facilities in the British Isles by S. A. Evans \& T. G. Shields available from RGIT Hyperbaric Research Unit, The Robert Gordon Institute of Technology, School Hill, Aberdeen AB1 1FR.

(2) The National Poisons Information Service (tel 071-635-9191) can also advise on the location, contact numbers and suitability of the nearest hyperbaric chamber. 


\section{REFERENCES}

Anand J. K., Crabbe G. G., Dunbar E. M., Farrell M. H., Pooley J. \& Roles N. (1988) Hyperbaric oxygen for carbon monoxide poisoning in England. British Medical Journal 296, 433.

Broome J. R., Pearson R. R. \& Skrine H. (1988) Carbon monoxide poisoning: forgotten not gone! British Journal Hospital Medicine 39, 298-305.

Clark C. J., Campbell D., Reid W. H. (1981) Lancet 1, 1332-1335.

Drug \& Therapeutics Bulletin (1988) Treatment of carbon monoxide poisoning. 26(20), 77-79.

Garland H. \& Pearce J. (1967) Neurological complications of carbon monoxide poisoning. Quarterly Journal of Medicine 144, 445.

James P. B. (1988) Hyperbaric oxygen, carbon monoxide, and cerebral oedema. British Medical Journal 296, 500-501.

Kindwall E. P. (1977) Carbon monoxide and cyanide poisoning. In J. C. Davis \& T. K. Hunt (eds) Hyperbaric Oxygen Therapy. Undersea Medical Society, Bethesda, Maryland.

Lowe-Ponsford F. L. \& Henry J. A. (1989) Clinical aspects of carbon monoxide poisoning. Adverse Drug Reactions: Acute Poisoning Review 8(4), 217-240.

Meredith T. \& Vale A. (1988) Carbon monoxide poisoning. British Medical Journal 296, 77-79.

Min S. K. (1986) A brain syndrome associated with delayed neuropsychiatric sequelae following acute carbon monoxide intoxication. Acta Psychiatrica Scandinavica 73, 80-86.

Myers R. A. M., Linberg S. E. \& Cowley R. A. (1979) Carbon monoxide poisoning: the injury and its treatment. Journal of the American College of Emergency Physicians 8, 479-484.

Myers R. A. M., Snyder S. K., Linberg S. \& Cowley R. A. (1981) Value of hyperbaric oxygen in suspected carbon monoxide poisoning. Journal of the American Medical Association 246, 2478-2480.

Myers R. A. M., Snyder S. K. \& Emhoff T. A. (1985) Subacute sequelae of carbon monoxide poisoning. Annals of Entergency Medicine 14, 1163-1167.

Noorkool D. M., Kirkpatrick J. N. (1985) Treatment of acute carbon monoxide poisoning with hyperbaric oxygen: a review of 115 cases. Annals of Emergency Medicine 14, 1168-1171.

Piantadosi C. A. (1987) Carbon monoxide, oxygen transport, and oxygen metabolism. Journal of Hyperbaric Medicine 2, 27-44.

Smith J. S., Brandon S. (1973) Morbidity from acute carbon monoxide poisoning at three year followup. British Medical Journal 1, 318-321.

Sukoff M. H., Ragatz R. E. (1982) Hyperbaric oxygen for the treatment of acute cerebral oedema. Neurosurgery 10, 29-38. 